\title{
Geographical Distribution of Fluoride and Its Effect on Animal Health
}

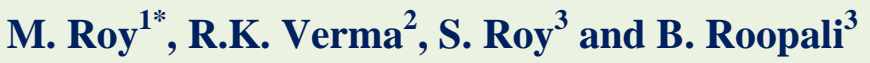 \\ ${ }^{I}$ Veterinary Physiology and Biochemistry department, College of Veterinary Science \& A.H., \\ Anjora, Durg (Chhattisgarh), India \\ ${ }^{2}$ Veterinary assistant Surgeon, Government of Chhattisgarh State, India \\ ${ }^{3}$ Veterinary Medicine Department, College of Veterinary Science \& A.H., Anjora, Durg \\ (Chhattisgarh) India \\ *Corresponding author
}

\section{A B S T R A C T}

\section{Keywords}

Fluoride, Cattle,

Health, Prevalence,

Environment,

Biological

\section{Article Info}

Accepted:

24 February 2018

Available Online:

10 March 2018
The present study was undertaken to monitor bovine fluorosis in Chhattisgarh. A total of 528 cattle suspected for fluorosis were examined and the percentage of prevalence of fluorosis was $23.84 \%$. Cattles of age group above 3 years were found to be more affected and females were more affected as compared to males for fluorosis. Maximum concentration of fluoride in water, soil and forage was recorded in Bastar district followed by Dhamtari, Bilaspur and Durg District. Higher concentration of fluoride was recorded in plasma, urine and hair in fluoride intoxicated cattle. The cases of fluorosis in cattle were diagnosed on the basis of clinical signs like dental mottling, lameness, bone deformity of hoof etc and fluoride concentration biological samples.

\section{Introduction}

Fluoride $(\mathrm{F}-)$ is an important anion, smaller amounts of fluoride are vital but toxic in larger amounts. Fluoride pollution in the environment occurs through natural and anthropogenic sources. Fluoride is frequently encountered in mineral deposits and generally released into ground water by slow natural degradation of fluoride bearing rocks. Fluoride distribution in groundwater depends on solubility of calcium fluoride level in groundwater which may be controlled by various factors like the geology, rock weathering and other chemical parameters present in groundwater, hydro chemical climate of the area. High fluoride concentration is due to the depth of the water coming from groundwater fluoride-bearing minerals (ATSDR, 2003). Fluorosis is predominant in various states of India, like, Gujarat Rajasthan, Jammu \& Kashmir Uttar Pradesh, Haryana, Bihar Jharkhand, Maharashtra, Madhya Pradesh, Chhattisgarh, Andhra Pradesh, Karnataka, Kerala Tamil Nadu and, Assam, Odisha and West Bengal (Hussain et al., 2004; Naklak et al., 2012). Water consumption is the major medium of 
fluoride intake by humans and animals (Narwaria and Saksena, 2012). However, lack of strict implementation of environmental laws and little use of modern technologies, the incidence of fluorosis appears to have shown rising trend in India over last few decades (Swarup et al., 2001).

Fluorosis is a major health problem in both human and animals all over the world (Cinar and Selcuk, 2005). It causes major health disorders like dental fluorosis, skeletal fluorosis and non-skeletal fluorosis. The advanced stages of irreversible skeletal and dental fluorosis effect livestock health status, which in turn has adverse effects on growth, development and economy of the country. Hydrogen fluoride gas, fluorosilic acid, sodium silicofluoride and sodium fluoride are major compounds responsible for fluoride toxicity in animals. Chronic fluoride toxicity is more common and important for human and domestic animal often characterized by pathological changes in teeth (dental fluorosis) and bone (osteofluorosis) (Ranjan and Ranjan, 2015). The preliminary manifestation of fluorosis are mottling of teeth and osteosclerosis of the skeleton. Besides these, non-skeletal fluorosis or toxic effect of fluoride on soft-tissue or organ systems, viz. gastro-intestinal disturbances, reproductive dysfunctions, neurological disorders and teratogenic effects have also been reported in the affected individuals (Choubisa et al., 2011).

\section{Materials and Methods}

\section{Collection of environmental samples}

A total of 320 samples of underground water from public hand pumps, vegetation from different grasslands and agriculture field and soil samples were collected from studied locations and were processed for estimation of fluoride levels by standard procedures.
Biological samples like Blood, urine and milk samples were collected from the animals of fluoride infected areas and processed to analyze fluoride level. Similar biological samples were also collected from 10 apparently healthy animals (healthy control) from dairy farm of College of Veterinary science and Animal Husbandry, Anjora, Durg. All the samples were collected and processed by standard procedure for estimation of fluoride ion concentration.

Fluoride concentration in samples was estimated by Ion Selective Electrode (ISE) of Orion as per the Orion application procedure and was read directly by microprocessor ionalyzer (Model 1901). Fluoride stock solution $\left(1000 \mathrm{gmL}^{-1}\right)$ was prepared from sodium fluoride and stored in polyethylene labware. Total ionic strength adjustment buffer (TISAB) solution contains $58 \mathrm{~g}$ of sodium chloride, $57 \mathrm{ml}$ of glacial acetic acid, 4 $\mathrm{g}$ of 1,2-cyclohexanediamine-N,N,N',N'tetraacetic acid (CDTA) and approximately $150 \mathrm{ml}$ of $6 \mathrm{~mol} \mathrm{~L}^{-1} \mathrm{NaOH}$ in a volume of $1000 \mathrm{~mL}(\mathrm{pH} \quad 5.0-5.5) 14 ; 15$. The TISAB solution regulates the ionic strength of samples and standard solutions and adjusts the $\mathrm{pH}$. After obtaining the results of analysis, all the areas were grouped into below optimal, optimal and above optimal Fluoride levels in drinking water as per the recommendations of the WHO (Bailey et al., 2006). Data were analyzed using Statistical Package for Social Sciences (SPSS version 12.0 Inc., Chicago II, USA).

\section{Results and Discussion}

\section{Fluoride in environment}

Fluoride exists fairly abundantly in earth crust and enters in ground water through natural process. Naturally occurring fluorides in groundwater are a result of the dissolution of fluoride-containing rock minerals by water 
(Kabata and Pendias, 1984). Soft water contains little fluoride while significant amount may present in hard water (Bansal et al., 2014). According to the World Health Organization (WHO), the maximum acceptable concentration of fluoride is 1.5 mg/l (WHO, 2006),

Fluoride concentration was estimated in water samples of public and private borehole water from Bastar, Dhamtari, Bilaspur and Durg districts of Chhattisgarh. Maximum concentration of fluoride was recorded in Bastar district that was more than maximum permissible limit (2.3ppm).whereas in Dhamtari, Bilaspur and Durg districts, concentration of fluoride in water samples were within permissible limit. Increased fluoride concentration in water samples were also observed by Choubisa et al., (1996) in Rajasthan, Muralidhar et al., (2000) from Karnatak, Sadat (2012) from Maharastra and Tiwari (2014) from Chhattisgarh. The variation of fluoride is dependent on a variety of factors like amount of fluoride in source rocks, the duration of contact of water with rocks, rain fall and soil temperature, oxidation- reduction process (Mahapatra, 2005)

All most similar increased concentration of fluoride was observed in forage in Dhamtari, Bilaspur and Durg districts whereas slight increase in values were observed in Bastar District. Which might be due to increase fluoride concentration in the water supplied for forage.

Application of phosphate fertilizers or sewage sludges, or from pesticides results in increased fluoride concentration in forage samples (Roy and Dass, 2013). Increased fluoride level in fodder crop was also observed by Ramteke et al., (2007) from Madhya Pradesh, Mishra et al., (2009) from Odisha, Swarup et al., (2001) from Rajasthan.
Increased concentration of fluoride in soil was recorded in Bastar district and comparatively lower levels in Dhamtari, Bilaspur and Durg districts. Mishra et al., (2009), Jadhav and Bogawar (2014) also reported fluoride concentration in soil samples. Bansal et al., (2014) observed that cattle grazing around fluoride rich soil and water might suffer with fluorosis.

\section{Fluoride in biological samples}

Increased fluoride level in water is responsible for dental and skeletal abnormalities (Dirisu et al., 2016). Prevalence of bovine fluorosis of districts Bastar, Dhamtari, Bilaspur and Durg was monitored on the basis of clinical signs like dental mottling, wavy appearance of table surface of inciser teeth, difficulties in mastication, lameness, overgrown hooves, stunted growth, emaciation, loss of glossiness of skin etc. and plasma fluoride level.

The data was then analysed according to age and sex of the animals. Overall 528 cattle were examined, out of that 126 cattle were found affected with fluorosis and percentage of prevalence of fluorosis was $23.86 \%$. The maximum prevalence percentage was observed in bastar district followed by Dhamtari, Bilaspur (Table 2).

According to age, during the course of study, the cattle of age group above 3 years were found to be more affected $(61.90 \%)$ than younger animals (Table 3) Patra et al., (2000) do agreed with this finding as they noted similar kind of results in Udaipur district of Rajasthan.

This finding might be due to fact that the calves are generally stall fed in the young age which decreases the chances of their contact with fluoride source. On other hand, bovine age group, more than 3 years were allowed to graze them daily exposure to fluoride. 
Table.1 Fluoride concentration in ground water, forage and soil $\left(\mathrm{mg} \mathrm{L}^{-1}\right)$ in districts of Chhattisgarh state

\begin{tabular}{|l|l|l|l|}
\hline Name of the districts & Water $\left(\mathrm{mg} \mathrm{L}^{-1}\right)$ & Forage $\left(\mathrm{mg} \mathrm{kg}^{-1}\right)$ & Soil $\left(\mathrm{mg} \mathrm{kg}^{-1}\right)$ \\
\hline Bastar & $2.00^{\mathrm{Aa}} \pm 0.64$ & $1.88^{\mathrm{Aa}} \pm 0.031$ & $0.72^{\mathrm{Ab}} \pm 0.03$ \\
\hline Dhamtari & $1.14 \mathrm{~A}^{\mathrm{ab}} \pm 0.15$ & $1.64^{\mathrm{Ab}} \pm 0.059$ & $0.74^{\mathrm{Ac}} \pm 0.089$ \\
\hline Bilaspur & $0.80^{\mathrm{Bab}} \pm 0.07$ & $1.76^{\mathrm{Ab}} \pm 0.064$ & $0.32^{\mathrm{Bac}} \pm 0.050$ \\
\hline Durg & $0.17^{\mathrm{Cb}} \pm 0.046$ & $0.42^{\mathrm{Ab}} \pm 0.049$ & $0.17^{\mathrm{Bbc}} \pm 0.051$
\end{tabular}

Values are expressed as mean \pm SE. Values having at least one common superscript (capital letters with in column and small letters within rows) do not differ significantly at $\mathrm{P}<0.05$.

Table.2 Showing prevalence of fluorosis in cattle of some districts of Chhattisgarh

\begin{tabular}{|l|l|l|l|}
\hline Studied area & $\begin{array}{l}\text { No. of total cattle } \\
\text { examined }\end{array}$ & No of affected cattle & $\begin{array}{l}\text { Percentage of } \\
\text { affected cattle }\end{array}$ \\
\hline Bastar & 185 & 53 & 28.64 \\
\hline Dhamtari & 111 & 23 & 20.72 \\
\hline Bilaspur & 112 & 22 & 19.64 \\
\hline Durg & 120 & 02 & 2.4 \\
\hline
\end{tabular}

Table.3 Showing age wise prevalence of fluorosis in cattle

\begin{tabular}{|l|l|}
\hline Age group & Percentage of affected cattle \\
\hline Below 1 year & 12.56 \\
\hline 1-3 years & 22.63 \\
\hline Above 3 years & 56.90 \\
\hline
\end{tabular}

Table.4 Showing sex wise prevalence of fluorosis in cattle

\begin{tabular}{|l|l|}
\hline Age group & \% affected cattle \\
\hline Male & 38.23 \\
\hline Female & 56.46 \\
\hline
\end{tabular}

Table.5 Showing Mean fluoride level in biological samples in some districts

\begin{tabular}{|l|l|l|l|}
\hline Name of the districts & plasma $(\mathrm{ppm})$ & urine $(\mathrm{ppm})$ & Milk $(\mathrm{ppm})$ \\
\hline Bastar & $0.78^{\mathrm{a}} \pm 0.04$ & $3.82^{\mathrm{b}} \pm 0.23$ & $0.05 \pm 0.04$ \\
\hline Dhamtari & $0.57^{\mathrm{a}} \pm 0.72$ & $1.73^{\mathrm{b}} \pm 1.04$ & $0.03 \pm 0.01$ \\
\hline Bilaspur & $0.60^{\mathrm{b}} \pm 0.56$ & $1.25^{\mathrm{b}} \pm 0.89$ & $0.02 \pm 0.001$ \\
\hline Durg & $0.04^{\mathrm{a}} \pm 0.15$ & $0.12^{\mathrm{a}} \pm 0.16$ & $0.00 \pm 0.001$ \\
\hline
\end{tabular}

Values are expressed as mean \pm SE. Values having at least one common do not differ significantly at $\mathrm{P}<0.05$. 
Table.6 Clinical signs observed in animals of studied locations $(n=126)$

\begin{tabular}{|l|l|l|}
\hline Disorders due to $\mathrm{F}^{-}$toxicity & $\begin{array}{l}\text { No. of animals showing } \\
\text { positive signs }\end{array}$ & Prevalence percentage \\
\hline Lame ness & 16 & 20.16 \\
\hline Unable to drink water in morning hours & 30 & 37.8 \\
\hline Dental lesions & 23 & 28.8 \\
\hline Skeletal deformity & 06 & 7.56 \\
\hline Reduced milk production & 27 & 34.04 \\
\hline Reduced reproductive performance & 48 & 60.48 \\
\hline
\end{tabular}

The rapid bone growth and remodeling, as in the younger calves, will remove fluoride from the blood stream, reducing the risk of dental fluorosis by lowering serum fluoride levels (Angmaar and Whitefrod, 1990).

The percentage of male and female fluorotic cattle did not differ significantly; however present study observed more prevalence in female animals (Table 4). The finding of present study is in accordance with findings of Modasiya et al., (2014).

\section{Fluoride in biological samples}

In animals of Bastar district, plasma fluoride concentration was higher as compare to Dhamtari and Bilaspur districts whereas least concentration of fluoride in plasma was observed in Durg district. Higher concentration of fluoride was observed in plasma and urine in fluoride toxicated cattle. Higher concentration of fluoride in plasma and urine from fluorotic animal has been reported by various authors (Gupta et al., 2013). The necessity of tracing fluorine concentrations in the environment is related to its influence on living organisms (Binder and Hohenegger, 1990). Non-significant increase of fluoride concentration was also observed in milk samples from the animals of affected locations. Higher concentrations of total fluorine in milk samples from the animals of fluoride intoxicated areas was also observed by Pasternak et al., (1998).

\section{Clinical finding}

Chronic ingestion of fluoride -rich fodder and water in endemic areas results in the development of fluorosis in animals e.g. dental discoloration, difficulty in mastication, bony lesions, lameness, debility and mortality (Patra et al., 2000). The fluoride affected cattle of the present study also observed dental mottling, light to deep yellowish discolouration of incisor teeth, pitting of teeth and wavy appearance of table surface of incisors difficulty in mastication. Lameness of varying degree was observed due to bony deformity of hoof (overgrown hoof) in osteofluorosis. The affected animals were unable to feed and drink, which markedly affected the performance of animals. Reduced productive and reproductive performances were observed in cattles of affected areas. Similar findings were observed by Kumar, (2017).

Snapping sound was heard from legs during walking. In addition to these, poor body condition, stunted growth, difficulty in mastication, cud dropping, inappetance, reduced milk production, infertility, diarrhoea and decreased draught power were observed in the affected bovine of the fluorotic areas. The present findings are in agreement in finding of Modasiya et al., (2014).

Present study has recorded that as there is a dose dependent relationship between fluorosis 
and fluoride level in environmental samples like water, forage and soil. Some degree of fluorosis has been observed at even low levels of fluoride exposure. Groundwater of a particular area should be studied thoroughly before its use for domestic purposes. Along with the clinical abnormalities, fluoride intoxication also affects the production and reproductive performances of cattle population and accordingly there is need to adopt some preventive measure against the toxic effects of fluoride.

\section{References}

Angmar-Mansson, B., Whitford, G.M. 1990. Environmental and physiological factors affecting dental fluorosis. J Dent Res. 69:706-713.

ATSDR (Agency for Toxic Substances and Disease Registry). 2003. Toxicological Profile for Fluorides, Hydrogen Fluoride, and Fluorine, U.S. Department Of Health And Human Services,

Bailey, F.K., Chilton, J., Dahi, E., Fewtrell, L. and Magara, Y. 2006. Fluoride in drinking water World Health Organization, Geneva, Switzerland.

Bansal, N., Kumar N. and Sharma, S.K. 2014. Determination of fluoride status in ground water of Rajasthan. Int. J. Pharma Chem and Biol.Sci. 4(3): 576592.

Binder, K. and Hohenegger, M. 1980. Fluoride metabolism. XXVIII International Congress of Physiological Sciences, Vienna,

Choubisa, S. L., Pandya, H., Choubisa, D. K., Sharma, O. P., Bhatt, S. K., Sompura, K. and Khan, I.A. 1996. Osteo-dental fluorosis in bovines of tribal region in Dungarpur (Rajasthan). J Environ Biol. 17:85-92.

Choubisa, S.L., Mishra, G.V., Sheikh, Z., Bhardwaj, B., Mali, P. and Jaroli V.J. 2011. Food, Fluoride, and Fluorosis in domestic ruminants in the Dungarpur district of Rajasthan, India. Res. Report, Fluoride. 44(2):70 -76.

Cinar, A. and Selcuk, M. 2005. Effects of chronic fluorosis on thyroxine, triiodothyronine, and protein-bound iodine in cows. Fluoride. 38:65-68.

Dirisu, C.G., Mafiana, M.O., Okwodu, N.E., and Isaac, A.U. 2016. Fluoride Contents of Community Drinking Water: Biological and Public Health Implications. Ame. J Water Resour., 4(3):54-57.

Gupta, A.R., Dey, S., Swarup, D., Saini, M., Saxena, A. and Dan, A. 2013. Ameliorative effect of Tamarindus indica $\mathrm{L}$. on biochemical parameters of serum and urine in cattle from fluoride endemic area. Vet. Arch. 83(5):487496.

Hussain, J., Sharma, K.C. and Hussain, I. 2004. Fluoride in drinking water in Rajasthan and its ill effects on human health. J. Tissue Res. 4: 263-267.

Jadhav, S.Z. and Bogawar, S. 2014. Fluoride in environmental compartments- A comprehensive review of literature. Int. J. Adv. Res. 2(3):629-636.

Kabata Pendias, A. and Pendias, H. 1984, Trace Elements in Soil and Plants., CRC Press, Boca Raton, Florida, 33431.

Kumar, S.P. 2017. Industrial Fluoride Pollution: Clinical Investigation On Chronic Fluoride Poisoning In Cattle. Intl J of Sci. Environ. Tech. 6(2):1061 1064

Mahapatra, M.K., Mishra A. and Das B.P., 2005, Fluorosis first reported in Naupada district of Orissa India., Ecology Environment and Conservation. 11(2): 277-280.

Mishra, P.C., Meher, K., Bhosagar, D. and Pradhan, K. 2009. Fluoride distribituion in different environmental segments at Hirakud, Orissa. Afric. J. Env. Sci. And Tech. 3(9):260-264. 
Modasiya, V., Bohra, D.L., Daiya, G. and Bahura, C.K. 2014. Observations of fluorosis in domestic animals of the Indian Thar desert, Rajasthan, India. Intl. J. Adv. Res 2(4):1137-1143.

Muralidhar, A., Sastry, K. N. V., Rao P. M. and Krishnamoorthy, U. (2000). Fluorosis in parts of Karnataka: an epidemiological study. Ind. J. Vet. Med. 20:86-87.

Naklak, B., Husain, I. and Husain, J. 2012. Community perception in adaptation of technical and traditional fluoride mitigation practices, Indian water week 2012- Water, Energy and Food Security: Call for solution, New Delhi, 10-14 April.

Narwaria, Y. S. and Saksena, D. N. 2012. Incidence of dental fluorosis in domestic animals of Shivpuri, Madhya Pradesh, Ind. J Environ Res. Dev. 7(1): 426-430.

Pasternak, K., Majdanik, S., Papierkowski, A. 1998. Fluorine in Milk. Polish J. Environ Studies. 7(4):243 - 244.

Patra, R.C., Dwivedi, S.K., Bhardwaj, B. and Swarup, D. (2000). Industrial fluorosis in cattle and buffalo around Udaipur, India. Sci. Total Environ. 253(1): 145150.

Ramteke, D. S., Onkar, R., Pakhide, D. and Sahasrabudhe, S. (2007). "Assessment of Fluoride in Groundwater, Food and Soil and its Association with Risk to Health." Proceedings of the 10th International Conference on Environmental Science and Technology, Kos Island, Greece.

Ranjan R. and Ranjan A. 2015. Fluoride toxicity in animals. Springer publications. Philadelphia.

Roy, S. Dass, G. 2013. Fluoride Contamination in Drinking Water - A Review. Resources and Environment. (3): $53-58$

Sadat, N. 2012. Study of Fluoride Concentration in the River (Godavari) and Groundwater of Nanded City. Int. J.Eng. Inven. 1(1):11-15.

Swarup, D, Dey, S, Patra, R.C. Dwivedi, S.K. and Ali, S.L. 2001. Clinicoepidemiological observation of industrial bovine fluorosis in India. Indian J. Anim. Sci. 71(12):1111 -1115.

Tiwari, M.K. 2014. To evaluate the significance of ground water in rural areas at Bilaspur particular position to fluoride attention. Jr. of Industrial Pollution Control. 30(2):361-363.

WHO Expert Committee Report on oral health status and fluoride use. 2006).WHO technical report series 846 , WHO, Geneva, pp-1-37.

\section{How to cite this article:}

Roy, M., R.K. Verma, S. Roy and Roopali, B. 2018. Geographical Distribution of Fluoride and Its Effect on Animal Health. Int.J.Curr.Microbiol.App.Sci. 7(03): 2871-2877.

doi: https://doi.org/10.20546/ijcmas.2018.703.331 